\title{
Prospective Filipino Teachers' Disposition to Mathematics
}

\author{
Restituto M. Llagas Jr. \\ Department of Mathematics and Natural Science - College of Arts and Sciences, University of Northern Philippines, Tamag, Vigan \\ City, 2700 Ilocos Sur, Philippines
}

Received October 27, 2020; Revised December 5, 2020; Accepted January 20, 2021

\section{Cite This Paper in the following Citation Styles}

(a): [1] Restituto M. Llagas Jr., "Prospective Filipino Teachers' Disposition to Mathematics, " Mathematics and Statistics, Vol. 9, No. 2, pp. 93 - 97, 2021. DOI: 10.13189/ms.2021.090202.

(b): Restituto M. Llagas Jr. (2021). Prospective Filipino Teachers' Disposition to Mathematics. Mathematics and Statistics, 9(2), 93 - 97. DOI: 10.13189/ms.2021.090202.

Copyright $(2021$ by authors, all rights reserved. Authors agree that this article remains permanently open access under the terms of the Creative Commons Attribution License 4.0 International License

\begin{abstract}
Studying mathematics comprises acquiring a positive disposition toward mathematics and seeing mathematics as an effective way of looking at real-life situations. This study aimed to correlate the disposition to Mathematics of prospective Filipino teachers to some teacher-related variables. The participants were the prospective Filipino teachers at the University of Northern Philippines (UNP) and at the Divine Word College of Vigan (DWCV). Two sets of instruments were utilized in the study - the self-report questionnaire and the Mathematics Dispositional Functioning Inventory developed by Beyers [1]. Frequency and percentage, weighted mean, and chi-square were utilized for data analysis. Results show that the overall disposition to mathematics of the participants is "Positive". The cognitive, affective, and conative aspects received a positive disposition. However, some items show an uncertain disposition to mathematics. The participants' profile variables have no significant relationship with their cognitive and conative disposition to mathematics. A training plan was conceptualized to provide information on the results of the study, to enhance the awareness and understanding of dispositions, to equip appropriate methods in solving mathematical problems, and to provide enrichment activities that will foster a positive disposition to mathematics and consequently will improve prospective teachers' and students' performance. Teachers are influential to the development of the students of effective ways of learning, doing, and thinking about mathematics. Understanding how attitudes are learned to establish an association between the teacher's disposition and students'
\end{abstract}

attitude and performance. Thus, fostering dispositions to mathematics through training improves prospective Filipino teachers' and students' performance.

Keywords Disposition, Mathematics, Prospective Teachers, Training Plan

\section{Introduction}

Learning mathematics encompasses concepts, techniques, and applications in real-life situations. It also comprises developing a disposition toward mathematics and understanding mathematics as a great way for looking at situations. The focus on teacher dispositions has grown over the years. These are referred to as "attitudes", "values", or "perceptions" (Knopp and Smith, [2]).

National Research Council [3] introduces the concept of mathematical disposition when they define a productive disposition to mathematics as a "habitual inclination to see mathematics as sensible, useful, and worthwhile, coupled with a belief in diligence and one's efficacy.

Dispositions are an individual's inclinations to act in each method and are analytical of patterns and actions. They answer the question of whether teachers are likely to apply the knowledge and skills they learn in programs or training they have attended to in their classroom teaching even when they are not being assessed (Borko, Whitcomb [4]). Teachers who can care about their students' academic achievements, those who are willing to exert the effort needed to ensure that the classroom is a fruitful 
learning setting, have features that may not be measured as possession of instructional knowledge and skills. These are teachers, who are through their actions and character, are establishing effective teaching dispositions.

Dispositions are critical to student success. Considering concerns with students' lack of comprehension in mathematics (Lee, Grigg, \& Dion, [5]), increased attention has been given to students' dispositions to mathematics and how they may be related to learning of mathematics. Furthermore, increasing concerns regarding the preparation of elementary school mathematics teachers (National Mathematics Advisory Panel, [6]) have culminated with a growing interest like prospective teachers' dispositions to mathematics and how they may affect prospective teachers' development of mathematical knowledge used for teaching.

Studying dispositions is vital in fostering effective teaching inside the classroom. Despite one's role in education, it cannot deny that education and learning influence all mankind. Disposition directly affects the delivery of teaching; those characteristics significant to teachers can be grasped in the way they teach their students.

Prospective teacher's dispositional cognitive, affective, and conative functions may influence the mathematical knowledge and understanding brought to bear when teaching mathematics. Studying teachers' dispositions in a comprehensive manner that addresses all three modes of functioning (cognitive, affective, and conative) may have relative 'contribution' of each to the overall relationship with achievement (Beyers, [1]).

Teachers are influential to students' development of effective ways of learning, doing, and thinking about mathematics. The ideas, attitudes, and anticipations of students about Mathematics have been substantial aspects underlying their school experiences and successes. An understanding of how attitudes are learned should establish an association between teachers' disposition and students' attitudes and performance. A student can acquire a positive attitude to mathematics because of learning to associate positive experiences with it. Moreover, positive support creates opportunities in forming a positive attitude toward Mathematics. However, there is still a negative outlook that will make the students develop a negative attitude towards the subject.

Grootenboer [7] stated that almost 70 percent of the primary student teachers surveyed held negative attitudes to mathematics, and Biddulph [8] found "... between one-half and two-thirds [of the teacher education students] had distinctly negative feelings about the subject." The students in the negative group articulated emotions that included lacking enthusiasm, nervousness, fear, "feeling a total failure", terrified, intimidated, and hatred.

Negative mathematical dispositions have been shown to hinder student mathematical achievement (National Research Council, [3]); and Beilock et al. [9] link elementary school students' negative disposition toward mathematics to negative mathematical dispositions in their teachers. It is then vital to examine the prospective teachers' disposition to mathematics since they will be the mentors of the future generation especially in the field of mathematics. Their disposition to mathematics may be conveyed to their students. When having a positive disposition, teachers find enjoyment in teaching the subject. They are more proficient and effective in the delivery of knowledge/skills/attitude in dealing with problems as compared to those who find Mathematics as a stressful subject.

Teachers' mathematical dispositions are established in the way they approach tasks, whether with confidence, enthusiasm to explore alternatives, determination, and interest, and how to reflect on their thinking. Teachers share both positive and negative perceptions of mathematics. Some teachers believed that Mathematics is the easiest but to others the hardest among all the disciplines. That perception must have been rooted in their experience in Mathematics. Some teachers tend to be comfortable and confident in their ability in handling Mathematics. Others perceived Mathematics as a complicated thing and as such, they might feed wrong information to learners. Some others feel awkward, anxious, and incompetent because of limited skills. Others still, find it interesting but lack the courage to teach the subject due to self-preservation.

Little work has focused on the dispositions of prospective teachers. Studying dispositions may help to deal with negative attitudes and perceptions about Mathematics, which may help institutions in forming training programs and courses to lessen these ways of thinking.

\section{Objectives of the Study}

This study aimed to correlate prospective teachers' disposition to mathematics to some teacher-related variables.

Specifically, it sought to answer the following questions: (1) What is the profile of the participants in terms of course and field of specialization, personal assessment of the participants' level of confidence in teaching, demonstration teaching rating, adequacy of instructional resources, utilization of teaching methods and approaches, utilization of ICT applications, ICT utilization in the different aspects of teaching, and level of importance on intrinsic work values of teachers?; (2) What is the disposition of the participants to mathematics in terms of Cognitive - Connections and Argumentation; Affective - Nature of Mathematics, Usefulness, Worthwhileness, Sensibleness, Mathematics Self-Concept, Attitude, and Mathematics Anxiety; and Conative?; (3) Is there a significant relationship between prospective teachers' disposition in Mathematics and the profile variables?; and (4) What training plan can be proposed based on the results of the study? 


\section{Materials and Methods}

This study utilized the descriptive correlational method of research. The descriptive part includes the determination of the profile of the participants in terms of course, the field of specialization, level of confidence in teaching, demonstration teaching rating, adequacy of instructional resources, teaching methods and approaches, utilization of ICT application, ICT utilization in the aspects of teaching, and intrinsic work values, and also the participants' disposition to mathematics in terms of cognitive, affective and conative aspects. The teacher-related variables were correlated with the disposition of the participants in Mathematics.

The 250 prospective teachers at the University of Northern Philippines and 29 prospective teachers at Divine Word College of Vigan during the Second Semester of the School Year 2017 - 2018 were utilized as respondents of the study

The convenient purposive sampling was used in the selection of the participants. The selected participants are the prospective teachers who were present during the administration of the questionnaire.

Two sets of instruments were utilized in the study: the self-report questionnaire and the disposition to mathematics questionnaire which was developed by Beyers [1].

The primary tool for gathering data in this study is a questionnaire/checklist which was administered to the participants. The questionnaire consists of two parts. Part I is on participants' profiles which include the course and the field of specialization/major of the participants. The second part is a personal assessment of the different teacher-related variables namely: level of confidence in teaching, demonstration teaching rating, adequacy of instructional resources, teaching methods and approaches, utilization of ICT application, ICT utilization in the aspects of teaching, and intrinsic work values. The level of importance of the intrinsic work values of teachers' questionnaire was adopted from the study of Florentino [10]. The teacher-related variables were identified based on the review of related literature and studies. The questionnaire was then validated by some experts and students who are not part of the participants. The suggestions given were used to improve the self-made questionnaires.

The Mathematics Disposition Functioning Inventory developed by Beyers [1] was utilized with the consent of the author. The items in the questionnaire are categorized into three: cognitive, affective, and conative functioning. It is composed of 60 items- 10 items for cognitive functioning, 44 items for affective functioning, and 5 items for conative functioning. There is one item that is the same as the other item used to test whether participants are answering questions genuinely as the respondent's selection. Beyers [1] provided the researcher with the Mathematics Dispositional Functioning Inventory Scales and Items
The prospective teachers responded to the 60 items using a 5-point scale. The questionnaire also contains reversed items $(*)$, indicating the best answer is to disagree over agree. Before this, the researcher asked permission from Beyers (2011) to adapt the MDFI, and the author granted permission to use the instrument.

Beyers [1] reported a coefficient of 0.90 for the instrument's internal validity and 0.938 for reliability.

To provide an understanding of the gathered data, the following statistical tools were utilized: frequency and percentage; weighted mean, and chi-square.

\section{Results and Discussion}

The study revealed the following findings:

\section{Profile of the Participants}

Most of the participants are enrolled in Bachelor of Elementary Education (BEEd), chose Content courses as their field of specialization. They expressed that they are confident enough in teaching, that's why they obtained an "outstanding" performance in their demonstration teaching.

The use of instructional resources was assessed as "Highly Adequate". However, the participants often use different teaching methods and approaches. Teachers change their teaching methods and approaches depending on the behavior of the students.

The teacher-centered approaches are always used by the participants. Also, they often use ICT tools in their class, showing a high extent of ICT utilization in the different aspects of teaching. Appropriate use of ICT improves the quality of education. The participants perceived a very high importance of intrinsic work values of teachers. Having a good working relationship performed better.

Level of disposition of the prospective teachers:

Table 1. Level of Disposition

\begin{tabular}{|c|l|}
\hline Disposition & Level \\
\hline Cognitive & \\
\hline Connections & Positive \\
\hline Argumentation & Positive \\
\hline Affective & \\
\hline Nature of Mathematics & Positive \\
\hline Usefulness & Positive \\
\hline Worthwhileness & Positive \\
\hline Sensibleness & Positive \\
\hline Mathematics Self-Concept & Positive \\
\hline Attitude & Positive \\
\hline Mathematics Anxiety & Positive \\
\hline Conative & Positive \\
\hline Overall & Positive \\
\hline
\end{tabular}

The overall disposition of the participants is Positive with all aspects - cognitive, affective, and conative 
disposition. The prospective Filipino teachers have an affirmative disposition to mathematics. They have the inclination to behave certainly in mathematics.

Relationship between the level of disposition of the prospective teachers and some teacher-related variables:

The participants' course, the field of specialization, assessment on their level of confidence in teaching, demonstration teaching rating, adequacy of instructional resources, teaching methods and approaches, utilization of ICT applications, ICT utilization in the different aspects of teaching, and level of importance of intrinsic work values of teachers do not affect their cognitive disposition to mathematics in terms of connections and argumentations. Thus, none of the profile variables affect the participant's cognitive disposition.

There is a significant relationship between the participants' assessment of their level of confidence in teaching and their affective disposition to mathematics in terms of the nature of mathematics.

Confidence in teaching is an important aspect of generating enjoyment for students in learning mathematics. Atallah, Bryant, \& Dada [12] considered self-assessment of mathematics ability as an aspect of disposition and can be related to the incorporation of confidence in mathematics teaching ability.

The participants' profile variables have no significant relationship with dispositional affective functioning in terms of usefulness and worthwhileness. This implies that the profile variables do not affect the usefulness and worth of mathematics. On contrary, Wilkins [13] believed that teachers with a positive approach to mathematics will generate a more positive approach within their students.

There is a significant relationship between the participants' assessment of the adequacy of instructional resources and their affective disposition to mathematics in terms of sensibleness. Also, there is a significant relationship between the participants' field of specialization, assessment on their level of confidence in teaching and utilization of ICT applications, and their affective disposition to mathematics in terms of mathematics self-concept. Teacher candidates' dispositions were indicative of the quality of their relationship with ICT (Arntzen [14])

The participants' course and field of specialization affect their affective disposition to mathematics in terms of attitude. However, methods and approaches do not affect the participants' attitude. This is contrary to Wilkins [13], that positive attitudes had a significant effect on teaching methods chosen by teachers.

The participants' field of specialization has also an effect on their affective disposition to mathematics in terms of mathematics anxiety. This implies that a positive disposition to mathematics would likely have an impact on a low level of anxiety.

Lastly, the profile variables of the participants have no significant association with their conative disposition. This means that the quality of teachers still depends on their knowledge, skills, and disposition.

\section{Training plan:}

It was revealed that the overall assessment of the prospective teachers' disposition to mathematics is "Positive". But there are items under affective disposition that received a "Negative" rating. Splitter [15] said that dispositions were conscious responses to situations. Therefore, a training plan was conceptualized to provide information on the results of the study, to enhance the awareness and understanding of dispositions, to equip appropriate methods in solving mathematical problems, and to provide enrichment activities that will foster a positive disposition to mathematics.

\section{Conclusions}

Disposition to mathematics enables students to persevere in more challenging problems, take some responsibility for their learning, and develop good work habits in doing Mathematics. (Glenda Lappan, NCTM [11])

Studying mathematics disposition encompasses beyond the concepts, procedures, and applications. Acquiring a positive disposition to mathematics is an effective way of looking at real-life situations. It is established in one's inclination to manifest their thinking. Innovative instructional approaches and techniques should be utilized by teachers to foster a positive disposition to mathematics. Teachers are influential to the development of the students of effective ways of learning, doing, and thinking about mathematics. Understanding how attitudes are learned to establish an association between the teacher's disposition and students' attitude and performance. Thus, fostering dispositions to mathematics through training improves prospective Filipino teachers' and students' performance.

\section{Acknowledgements}

The author would like to acknowledge the Graduate School of St. Paul University Philippines, University of Northern Philippines, and Divine Word College of Vigan.

\section{REFERENCES}

[1] Beyers, J. E. R., Development and Evaluation of an Instrument to Assess Prospective Teachers' Dispositions with Respect to Mathematics", International Journal of Business and Social Science, 2, 20-32, www.ijbssnet.com/j ournals/Vol_2_No_16_September_2011/3.pdf (accessed May 10, 2017) 
[2] Knopp, T.Y. and Smith R.L., "A Brief Historical Context for Dispositions in Teacher Education”, http://www.iserjournal s.com/journals/eurasia/articles/10.12973/eurasia.2016.1536 a (accessed May 10, 2017)

[3] National Research Council (2009), "Learning Mathematics in Early Childhood: Paths toward Excellence and Equity", www.nap.edu/catalog/12519/mathematics-learning-in-early -childhood-paths-toward-excellence-and-equity (accessed May 11, 2017)

[4] Borko, H. \& Whitcomb, J., “Apples and Fishes: The Debate over Dispositions in Teacher Education”, Journal of Teacher Education, 58, 359-364,www.colorado.edu/education/sites/ default/files/attached-files/apples_and_fishes.pdf (accessed May 10, 2017)

[5] Lee, J., Grigg, W., \& Dion, G., "The Nation's Report Card: Mathematics 2007 (NCES 2007-494)", Washington, DC: National Center for Education Statistics, Institute of Education Sciences, U.S. Department of Education, www.nces.ed.gov/nationsreportcard/pubs/main2007/20074 94.asp (accessed May 11, 2017)

[6] National Mathematics Advisory Panel, "Foundations for success: The final report of the National Mathematics Advisory Panel", Washington, DC: United States Department of Education, www.ed.gov/about/bdscomm/list /mathpanel/report/final-report.pdf (accessed May 11, 2017)

[7] Grootenboer, P. J., "Preservice Primary School Teachers' Perceptions of their Experiences of School Mathematics", Journal of Educational Inquiry, 1, http://www.soe.waikato.a c.nz/Journal/Math_Experience.htm (accessed May 10, 2017)

[8] Biddulph, F., “The Legacy of Schooling: Student teachers'
Initial Mathematical Feelings and Competence", Mathematics Teacher Education and Development, 1, 64-71, www.citeseerx.ist.psu.edu/viewdoc/download?doi=10.1.1.5 28.9864\&rep=rep 1\&type $=$ pdf (accessed May 11, 2017)

[9] Beilock, S. L., Gunderson, E. A., Ramirez, G., \& Levine, S. C., "Female Teachers' Math Anxiety affects Girls' Math Achievement", www.ncbi.nlm.nih.gov/pubmed/20133834 (accessed May 11, 2017)

[10] Florentino, C., "The Teaching of Chemistry in State Universities and Colleges in Region I", Unpublished Dissertation. University of Northern Philippines, Vigan City

[11] National Council of Teachers of Mathematics, "Mathematical Dispositions: Professional Development for Teachers", https://www.teachervision.com/mathematica 1-dispositions (accessed May 10, 2017)

[12] Attallah, F., Bryant, S.L., \& Dada, R. "A research framework for studying conceptions and dispositions of mathematics: A dialogue to help students learn", http://search.proquest.com/docview/761066240?accountid= 10382 (accessed January 7, 2018)

[13] Wilkins, J. "The impact of teachers' content knowledge and attitudes on instructional beliefs and practices", https://files.eric.ed.gov/fulltext/ED471775.pdf (accessed January 7, 2018)

[14] Arntzen, J. “Teacher candidates' imaginative capacity and dispositions toward using ICT in practice", https://open.library.ubc.ca/cIRcle/collections/ubctheses/24/i tems/1.0220766 (accessed January 7, 2018)

[15] Splitter, L. (2010). Dispositions In Education: Nonentities Worth Talking About. Educational Theory, 60(2), pp. 203-230. doi:10.1111/j.1741-5446.2010.00354.x 